\title{
A festiva devoção no Círio de Nossa Senhora de Nazaré
}

\author{
ISIDORO ALVES
}

入 O MÊS de Outubro/Em Belém do Pará/São dias de alegria e muita fé/ Começa com extensa romaria matinal/O Cirio de Nazaré. Assim cantou, em seu samba enredo de 1975, a Escola de Samba Unidos de São Carlos, hoje Estácio de Sá, em seu desfile de carnaval do Rio Janeiro, enredo que foi repetido por outra Escola, a Unidos do Viradouro, em 2004, portanto, quase trinta anos depois. E assim tem sido a Festa de Nazaré por mais de dois séculos, desde que realizada e oficializada pela primeira vez, em 8 de setembro de 1793 (Viana, 1904). São dias sim, de um intenso, por vezes dramático, encontro que envolve fé, alegria, festejos e sentimentos profundos.

A procissão do Círio de Nazaré, ao levar às ruas de Belém, capital do Estado do Pará, quase dois milhões de pessoas em 2004, repetiu um ritual festivo de mais de dois séculos, cujos significados são objeto deste trabalho, o qual atualiza, em sua interpretação e incorporação de novos eventos, um processo de investigação que começa nos anos de 1970, sistematizado no livro O Carnaval DevotoUm Estudo sobre a Festa de Nazaré, em Belém (Alves, 1980) e em trabalhos posteriores.

Foi, de certo modo, a utilização do Círio de Nazaré em outro grande momento festivo da vida brasileira que consagrou a denominação Festa do Círio de Nazaré, para o que era a Festa de Nazaré que começava com o Círio de Nazaré. Dessa forma, o Círio de Nossa Senhora de Nazaré, considerado como a maior procissão religiosa do Brasil, que leva às ruas de Belém, neste século XXI, milhões de pessoas, revela-se, e assim é entendido, como uma das manifestações mais significativas das expressões da Festa brasileira e pela qual se pode fazer uma leitura da sociedade e da cultura. No caso paraense e amazônico, o Círio é uma festa que reúne dois grandes aspectos do sistema ritual brasileiro (cf. Da Matta, 1979). Por ser um evento religioso que festeja uma santa padroeira, relaciona-se ao sagrado, às comemorações da ordem e da hierarquia sacralizada e, ademais, permite uma intensa gama de informalidade festiva, de confraternização e solidariedade.

\section{Os sentidos da festa}

Todos os anos, a partir do segundo domingo de outubro, realiza-se a Festa do Círio de Nazaré, já definida aqui como um "complexo ritual”, pois reúne não só várias procissões, mas completa-se com o arraial (originalmente uma grande feira) e o almoço do Círio. Em torno desse eixo ritual prático é que propomos 
uma interpretação do Círio e da Festa de Nazaré que envolve as dimensões sacralizadas e devocionais com aquelas carnavalizadoras, informais e comunitárias (Alves, 1980).

No conjunto da Festa que Da Matta (1981) identificou apropriadamente com o que chama de carnavais sagrados e que se desenrola por quinze dias, há uma expressão da vida social, através dos valores e significados que são postos em evidência. Visto e lido como uma performance ritual, a idéia de carnavalização da vida social, em que Bakhtin (1987) havia envolvido a cultura popular da Idade Média e do Renascimento e que se expressam na obra, por ele analisada, de Rabelais, está impregnada não de manifestações que invertem o sistema social, mas que estabelecem uma espécie de neutralização, daí o peso igual e simétrico entre a manifestação popular carnavalizada e o ato contrito do gesto respeitoso em uma solenidade também voltada para o sagrado.

Sendo uma festividade em louvor a Nossa Senhora de Nazaré, de evidente origem portuguesa, está, no entanto, impregnada dos significados e das formas particularmente expressivas do mundo paraense e amazônico. Esse é um dado a ser considerado na análise dos rituais religiosos no Brasil. Mantendo as linhas estruturais básicas em sua realização, tais eventos, ainda que considerados em suas origens portuguesas, passam, em sua versão impregnada de um catolicismo popular, pelos esquemas culturais e pelo sistema de significados e significações que lhes são próprios (Cf. Sahlins, 1990): o mito de origem, a comensalidade, a patronagem do Santo (o sistema de santos padroeiros e/ ou de devoção), o que é efetivamente festejado etc.

Durante quinze dias de outubro, o evento principal é o Círio, procissão que percorre a cidade entre a Catedral da Sé e a Basílica de Nazaré. Desde o primeiro Círio que o trajeto e a representação simbólica da procissão não se modificaram. Círio é uma palavra que designa uma grande vela pascal e que, tanto em Portugal como no Pará, “designa romaria ou procissão em que avultam - como promessas ou ex-votos - velas, cabeças, pés, mãos, animais, barcos e outros objetos feitos de cera" (Dubois, 1953, p. 49).

O Círio a que hoje assistimos é bem mais do que uma simples procissão devocional. Além disso, ele é ponto inicial para um ciclo de Círios que ocorre em todo o interior do Estado do Pará, com os santos padroeiros das cidades e localidades, envolvendo procissão e festa e no qual se desenrola o que denominamos de um sistema de intercâmbio de pessoas, interesses e manifestações simbólicas marcadas pelas trocas e um amplo sentimento de complementaridade e reciprocidade (Alves, 1993).

A descrição que o historiador Artur Viana faz do primeiro Círio de Belém em 8 de setembro de 1793 e sua interpretação das Festas Populares do Pará (1904) é significativa tanto da estrutura do ritual como das transformações em sua performance. Trata-se de um desfile ao mesmo tempo militar, religioso e social. Essa ordem no desfile sinaliza a marca inicial da procissão. $\mathrm{O}$ mesmo historiador 
que a descreveu, no início do século passado, deplorava que nada restava do primeiro Círio e da primeira feira, Viana reclamava "da turbamulta dos devotos que enxameam ridiculamente em volta à Santa em desrespeitoso desalinho, num atropelo e aglomeração pouco decentes e numa vozeria ensurdecedora" acrescentando que "a disputa dos logares faz-se violentamente aos encontrões, à viva força muitas vezes, entre homens e mulheres promiscuamente, sem recato e sem respeito" (Viana, 1904, p. 327). Há, ao longo de sua história, uma espécie de "apropriação popular" de uma festa que foi inicialmente oficializada para sacralizar o poder na Província, transformando-a no grande evento por meio do qual as diferentes camadas sociais vivem, a partir de um símbolo comum, a Virgem de Nazaré, uma experiência comunitária sem igual.

Compreender as duas dimensões, devocional e informal, significa compreender o verdadeiro sentido da Festa, pois, ao conduzir a Santa padroeira, os devotos estabelecem com ela uma relação direta, não mediada pela hierarquia religiosa, situação essa, aliás, que, ao longo da história do Círio de Nazaré, foi sempre um ponto de tensão em razão da qual ocorreram as grandes questões do Círio (Alves, 1980, p. 94) A realização popular sempre se impôs como expressão de uma religiosidade que se impregnou de outros valores além dos religiosos strictu senso.

Uma das características da Festa de Nazaré é que ela é um ponto nodal (fim e início) de um ciclo no calendário regional que compreende um tempo muito particular - daí as expressões referentes ao Círio como o Natal dos paraenses, com as correspondentes saudações de um "um bom ou feliz Círio" nos encontros entre pessoas às vésperas do evento, tal como se deseja um bom Natal ou um feliz Ano Novo. O cumprimento ritual atualiza a passagem de um ciclo a outro, revela os desejos comunitários e o sentimento de pertencimento e a renovação de relações socialmente estabelecidas. Por isso mesmo, em seus desdobramentos, a realização da Festa durante a quinzena vai mostrar esses aspectos valorativos que lhes são próprios.

\section{Um ciclo de procissões}

A quinzena de festejos que começa com o Círio, no segundo domingo de outubro, é composta por um conjunto de eventos e várias procissões. Na verdade bem antes, pois os preparativos incluem a peregrinação da imagem da Nossa Senhora de Nazaré pelas casas, entidades diversas como a preparar o conjunto de eventos que virá em seguida. Antes do Círio, são realizadas duas grandes procissões, no sábado: a Trasladação, à noite, e o Círio fluvial, criação mais recente e que tem um grande trajeto nas águas da baía de Guajará, desde a Vila de Icoaraci até o porto de Belém, de onde, em carro aberto, vai até a Basílica de Nazaré.

A trasladação dá-se no percurso invertido: saindo do Colégio Gentil Bittencourt, quase ao lado da Basílica de Nazaré, leva a Santa, em uma Berlinda ornamentada, até a Catedral de Belém. No dia seguinte, a procissão retorna pelo mesmo caminho, já então como o Círio de Nazaré. O Círio fluvial, com a imagem da santa sendo levada por um navio da Marinha e acompanhada por deze- 
nas de embarcações de grande ou pequeno porte, de certa maneira alude a uma forte relação das manifestações religiosas na Amazônia com as águas e se completa com os trajetos invertidos da trasladação e do Círio. As várias procissões (a dos motoqueiros, o Círio das crianças, o no final o Recírio) são manifestações desse grande movimento de pessoas em que se transforma a Festa de Nazaré. Este ciclo de procissões implica a saída/ entrada da Santa Padroeira no espaço da cidade a ser consagrado: sua saída do Colégio, ida à Catedral, retorno no Círio para a Basílica de Nazaré e, finalmente, o retorno ao Colégio. Basicamente, os trajetos do Círio e da Trasladação não se modificaram, desde a sua primeira realização. Mas, a procissão "se destacou pela sua extrema popularidade" representando assim "o predomínio de uma romaria de origem portuguesa sobre as fórmulas tradicionais de origem oficial, as procissões ou festas reais, impostas por lei", conforme indica Eidorfe Moreira que conclui afirmando que "o Círio e a Cabanagem são os dois maiores exemplos do poder afirmativo das massas na história paraense" (Moreira, 1971, p. 15).

A descrição do Círio de Nazaré, em três momentos, dimensiona bem o seu desdobramento histórico, em mais de dois séculos, até chegar aos tempos atuais. Viana assim descreve o primeiro Círio em 1793:

a imagem foi transportada na véspera d'aquele dia à noite da ermida para o palácio do governo. Pela escura estrada do Utinga, onde não chegara a mortiça iluminação de azeite da cidade, escoou-se a multidão que cercava o carro da santa até desembocar no largo da Campina (atual praça da República) então sem as suas lâmpadas de arco-voltaico, sem o seu belo teatro, sem os seus circos e restaurantes e apenas com o seu cemitério lúgubre, onde jaziam somente os cadáveres dos infelizes escravos e dos pobres flagelados pela varíola. No dia seguinte, à tarde, com todo o esplendor possível a uma estréia, desfilou do palácio a romaria; na frente e no couce marchava toda a tropa da cidade, os esquadrões de cavalaria em primeiro lugar, os batalhões de infantaria depois e atrás as baterias de artilharia; adiante do carro da santa seguiram uma fila de séges palanques e serpentinas, com senhoras, e duas linhas de cavaleiros, trajando vestes de gala; a turba cercava o carro, e logo após este, destacava-se o governador e os membros das suas casas civil e militar, em primeiro uniforme e cavalgando bons cavalos (Viana, 1904, p. 237).

O jornal Treze de Maio, publica, em sua edição de 27 de setembro de 1855, um minucioso programa da Festa de Nossa Senhora de Nazareth do Desterro no Ano de 1855 , com a descrição da procissão no dia 14 de outubro daquele ano (mantendo-se a grafia da época):

Às 6 horas da manhã sahirá o Círio da Capella e fará sua digressão, pela frente do Palácio da Presidência até o canto da rua do Espírito Santo, pela qual irá até ao Paço Municipal, em frente do qual seguirá até ao Convento do Carmo e d'ahi pela rua do Norte, largo da Sé, rua do Marcadores, rua de Santo Antônio, travessa dos Mirandas, praça de Pedro $2^{\circ}$. e estrada de Nazareth. Romperá o séquito um carro perfeitamente enramado de flores e murta, e com as bandeiras das Nações christães, o qual irá soltando girândolas de fogo 
artificial em todo o transito do Círio. Seguir-se-á o Anjo Custódio, vestido com o maior gosto e primor, montado em um lindo e bem ajaesado cavallo [...] Logo após irão á dextra dous formosos cavallos d'Estado do mesmo Anjo, bem ataviados e guiados por dous homens vestidos ao gosto Romano. O Milagre feito pela Virgem de Nazareth, em favor dos infelizes náufragos do Brigue Portuguez S. João Baptista, será então despertado à recordação dos fieis pelo Escaler em que se salvaraõ, o qual será conduzido por homens dedicados á vida marítima. O acompanhamento dos cavalleiros e das demais pessoas em carrinhos precederá as carruagens que conduzirem os Exmos. Snrs. Presidente da Província, Prelado Diocesano e Comandante das Armas, fechando o préstito a Berlinda da SENHORA tirada por parelhas ricamente ajaezadas, sendo estas guiadas por dous homens vestidos à Romana. A imagem irá nas mãos do Conego Capellão do Governo da Província, assistido por dous Anjos com brandões acesos, ambos primorosamente vestidos. A lusida Secção de Companhia de Cavallaria da Guarda Nacional flanqueará a Berlinda da SENHORA desfilando atraz uma marcial Divisão compostas dos briosos $1^{\circ}$ Batalhão de artilhara da mesma Guarda, $1^{\circ}$ Batalhão de Artilharia de linha, 11 de Infantaria, e Corpo de Polícia Provincial, todos em grande uniforme. A sahida do Círio será annunciada por uma salva de 21 tiros de grossa artilharia do Forte do Castelo, e a passagem delle por cada uma das Praças da Cathedral, das Mercês e de Pedro $2^{\circ}$ será saudada pelo estampido de 21 bombas detonantes. Chegado o Círio ao Arrayal e recolhida a Imagem da Milagrosa Senhora á sua Ermida, dará a referida Divisaõ tres salvas de mosquetaria, depois do que, se recolherá á seus Quartéis, ficando no Arrayal destacamento do costume.

Nos anos de 1970 (a partir de 1974), descrevemos o Círio (Alves, 1980) como composto de três segmentos ou o que chamamos de espaços em movimento: um núcleo estruturado constituído pelas autoridades civis, militares, eclesiásticas, políticas, altos funcionários, irmandades religiosas e convidados, que portando crachás, ficavam dentro da corda (já então um elemento fundamental na procissão) ou mais perto da imagem da Santa; um segmento intermediário ou liminar, composto pelo povo que segura a corda e "puxa" a Berlinda, e um terceiro segmento, composto pela grande massa de acompanhantes. Também como nas descrições anteriores, contingentes militares, representando Exército, Marinha, Aeronáutica e Polícia Militar, ladeavam o núcleo central da Procissão. Tais segmentos eram antecedidos pelos carros alegóricos: o carro de foguetes na forma de uma torre de castelo e puxado a boi; o carro dos milagres que evoca o milagre do nobre português D. Fuas Roupinho; barcos que recolhem as promessas ao longo do percurso (uma configuração atual do brigue S. João Batista); carro dos anjos e a Berlinda que conduz a Santa. Nas últimas edições do Círio, foi acrescentado um carro que reproduz o aparecimento da Santa ao caboclo Plácido, cuja narrativa constitui o mito de fundação do culto e da festa de Nazaré de que trato mais adiante.

O extraordinário crescimento populacional, a ampla divulgação nacional do Círio, o apelo turístico e religioso e as facilidades de transporte têm levado ao evento uma multidão incalculável, derivando daí mudanças que, no essencial, 
não modificam o que estruturalmente foi sendo estabelecido ao longo dos séculos. E, em alguns casos, mudanças foram objeto de polêmicas, como é o caso da corda. Estabelecida ainda no século XIX, após um episódio em que a Berlinda que conduz a santa ficou presa em um atoleiro, a corda atrelada à Berlinda é puxada por devotos pagadores de promessa. Faz parte do segmento liminar a que me referi acima: gente descalça, fazendo um sacrifício por vezes doloroso fisicamente, mas extremamente alegre, jocoso em vários momentos. Tornou-se o centro de muitos debates nos últimos anos. É um símbolo da relação direta com a Santa e estabelece um forte elo entre o mundo da divindade e o mundo dos homens em seu cotidiano.

As promessas referem-se, freqüentemente, a momentos cruciais, crises de vida, saúde/ doença etc. com a inclusão, nos últimos anos, de temas típicos de nosso tempo, como sucesso nos vestibulares, acesso a empregos e à casa própria. A representação formal nos últimos anos está restrita quase que às autoridades religiosas, ainda que a presença simbólica da representação militar permaneça. Autoridades civis e políticas foram deslocadas para espaços "especiais" e de visão "privilegiada" ao longo do percurso da procissão. Segue sendo um evento que festeja e consagra a ordem, mas com essa disposição sendo contrabalançada e "neutralizada" pela imensa manifestação popular marcada pela música, pelo canto e pelo ritmo do som das bandas militares. A contrição não é permanente: as manifestações de alegria com o encontro e reencontro entre as pessoas, a jocosidade e um certo despojamento, estão entrelaçados no contexto do ritual. A linguagem em jogo no Círio vai do mais estritamente formal, que implica a relação com o sagrado, ao mais estritamente informal, que a aproxima da inversão (sem nunca chegar a tanto) carnavalizadora.

\section{Mito atualizado}

A Festa atualiza o mito de fundação do culto e da festividade de Nazaré, especialmente ao sacralizar os espaços percorridos pela procissão e ao definir o evento como a mais forte manifestação da identidade paraense (a idéia de uma identidade regional) pelos personagens e pelas situações vividas na performance ritual. Em certo sentido, não difere, formalmente, de outras lendas e narrativas que consubstanciam os cultos à Virgem Maria em muitos outros países e cidades. O Círio reproduz os caminhos que já aparecem na história do aparecimento da imagem da Santa. A história consagrada diz que um caboclo chamado Plácido achou na mata uma imagem que pensou, logo, ser de algum peregrino, levandoa para sua casa. Mas, para espanto seu, ela voltou ao lugar de origem, onde tinha sido achada. A notícia logo se espalhou e foram muitas as pessoas que acorreram à casa de Plácido para comprovarem o milagre ocorrido. Conta ainda a narrativa popular que o governador da província, na época (século XVIII), mandou buscar a imagem encontrada e a colocou sob guarda no Palácio do Governo. Para surpresa de todos, no dia seguinte, ao abrirem o compartimento em que havia sido guardada, a imagem não mais lá se encontrava, tendo voltado ao seu lugar 
original. A partir de então foi erguida uma ermida no local em que a imagem foi achada, logo transformada em um local de devoção. Sucessivos acréscimos e mudanças transformaram a pequena ermida na atual Basílica de Nazaré.

Essa área, originalmente, era pouco habitada, estava no "interior" em relação à cidade. O culto a Nossa Senhora de Nazaré já existia na Vigia (Maués, 1995), como de resto o culto a outros santos, dadas as origens portuguesas do catolicismo popular que então vai se constituindo, mesclando-se a uma visão muito particular, mas muito matizada, do sistema religioso paraense e amazônico (Cf. Galvão, 1955 e Maués, 1995). O mito põe em destaque alguns aspectos importantes para o entendimento do culto à Virgem de Nazaré: primeiramente o tipo de pessoa que encontra; o santo encontrado e o lugar; a apropriação "oficial" e a popularização da devoção e o movimento que a Santa faz de ida e retorno, em um espaço que cada vez mais se torna o centro da cidade de Belém.

O primeiro ponto diz respeito às características do achado da imagem: um caboclo chamado Plácido, portanto, um homem do interior, pobre, pertencente a uma categoria que vai ser o modelo do romeiro que presta devoção à Santa. Este ponto liga-se a um segundo aspecto, que é o caráter de peregrinação, portanto, de movimentação de pessoas, que caracteriza o culto à Virgem. Um terceiro aspecto diz respeito à origem popular da devoção e sua apropriação "oficial" e, finalmente, o poder milagroso da Santa, que se torna mais forte e presente com o correr dos anos e à originalidade do achado.

No que respeita ao primeiro aspecto, o mesmo parece corresponder a um fato comum ao aparecimento milagroso de santos ou achados de imagens (vejase o caso das imagens das Virgens de Guadalupe, Fátima e Aparecida): em geral, são pessoas simples (caboclos, camponeses, nativos, pescadores, etc.) que as encontram. Assim, na origem, supõe-se que os pobres, os desvalidos, os piedosos, os que não dispõem de poder, é que são capazes do milagre da visão do santo. Dessa forma, a devoção institui-se como um "culto popular" nascido no meio do povo, que pela fé - verdadeira - tem acesso aos poderes miraculosos da Virgem. Esse poder não só se refere aos casos pessoais, onde cada um estabelece o seu "contrato" de fé, mas a eventos múltiplos, como epidemias de bexiga, sarampo e cólera, nos séculos XVIII e XIX, que acometeram a população de Belém que vivia em condições ambientais e sanitárias inadequadas (para um estudo a respeito da cólera, no século XIX, veja-se Beltrão, 2004).

Ao atualizar o mito do aparecimento da Santa, o Círio dá ênfase à origem do culto: daí o gesto piedoso, o despojamento nas atitudes, a reverência ao sagrado, as oferendas em contrapartida ao milagre. A procissão, em seu deslocamento espacial, refaz a ligação iniciada em 1793 entre o Palácio do Governo e a Basílica de Nazaré, reproduzindo assim o que Moreira chama de um "clímax de uma migração periódica de fundo religioso". A observar que, no princípio, essa mobilização se fazia da cidade para o interior, uma vez que Belém, na época, século XVIII, era ainda um núcleo reduzido. Posteriormente, essa mobilização 
passou a ser feita do interior para a cidade, pois os romeiros deslocam-se de todas as áreas da região (e do Brasil) para vivenciar os dias da Festa. Para Moreira (1971) o efeito simbólico desse movimento proporcionado pelo Círio atuaria como "força aglutinadora" de populações que se espalhavam pela região e tendo como função a fixação de "certos padrões de comportamento coletivo" (Moreira, 1971, p. 16).

Nesse sentido é que a Festa de Nazaré constitui um marco essencial do que culturalmente é importante para um modo de vida regional. A atualização do mito, além de ressaltar esses padrões, põe em destaque as instâncias de identificação regional: a Festa de Nazaré é uma festa dos paraenses, intrinsicamente regional, e assim é percebida e realizada. Reflete os desejos e anseios de uma população que se orgulha do compartilhamento de valores comuns, sejam eles efetivos, desejados ou idealizados, essencializados na condição humilde daquele que achou a imagem de Nossa Senhora de Nazaré, "pobre e mestiço” (Moreira, 1971, p. 13) e seus continuadores. Por isso mesmo é que os paraenses, nas mais diversas cidades do Brasil, realizam o seu Círio no segundo domingo de outubro: seja no Rio de Janeiro, São Paulo, Brasília, Recife etc. O Círio é reproduzido e os valores regionais compartilhados da mesma forma, seja na procissão, nos pequenos arraiais montados ou na venda e consumo de comidas paraenses.

Não deixa de ser significativo que um dos carros do Círio é uma alegoria do milagre que salvou, no século XII, o nobre português D. Fuas Roupinho, remetendo o culto à Virgem de Nazaré aos primórdios portugueses de onde se origina. Ganha, no entanto, um conteúdo regional com o relato mítico do achado em plena mata paraense por um personagem pertencente a uma categoria social ligada ao "homem do interior". Nessa categoria, estão implicados estilos de vida, comportamentos, costumes, enfim, um conjunto de modos de ser que, de um certo modo, caracterizaria os devotos e romeiros nas festas religiosas dos santos padroeiros, das quais o ciclo de círios é a plena manifestação. Havendo uma hierarquia de santos e de categorias sociais, os eventos festivos possibilitam um encontro e a realização no tempo da festa de uma temporalidade propícia à reciprocidade social. O Círio de Nazaré em Belém é como o grande estuário para onde correm os afluentes festivos das localidades do interior do Estado do Pará, as quais realizam os seus Círios e homenageiam seus padroeiros. Todos subordinados à hierarquia do Santo Padroeiro maior, Nossa Senhora de Nazaré.

\section{O tempo da festa}

Já afirmamos que o Círio de Nazaré é o ponto principal de um ciclo, de um tempo e de um calendário. Ele é o ponto de chegada e de partida de um novo período, de um novo tempo. Por outro lado, o ciclo de círios a que me referi e que ocorre por todo o interior do Estado do Pará é a expressão ritual de um amplo intercâmbio ritual entre interior e cidade, entre espaços e tempos diferenciados que se encontram no tempo da festa propício à realização de uma temporalidade cósmica, circular. No caso do Círio, esse tempo cíclico parece 
essencial como valor reconhecido. Ele estabelece um outro calendário que corre paralelo àquele contínuo do tempo cronológico e das atividades cotidianas. A sociedade pára para viver um momento especial. Nessa parada no tempo - os quinze dias da Festa - os paraenses e seus convidados destacam os valores, sentimentos, um modo de vida, um estilo de comensalidade, e configuram um movimento de pessoas no intenso intercâmbio entre cidade/ interior/ exterior.

O tempo da festa é um tempo aberto e que se abre a todas as possibilidades de manifestação e onde as diferenças se neutralizam. Ao calendário de um tempo cronológico convencional organizam-se simultaneamente outros mais profundos de vida e das relações sociais em curso. É assim que o Círio de Nazaré é percebido como o Natal dos paraenses, pois ele é um ponto de partida e de chegada de um calendário de vida que vincula todos os eventos da mesma ordem e em menor escala. No ciclo de círios, o tempo da festa e o calendário que a partir dele se organiza permitem o intercurso permanente entre populações de diferentes localidades. Na Amazônia, há um sistema de festas (de santos, especialmente) que está profundamente enraizado na cultura e na vida social, pois é nos períodos de festas que a população paraense realiza as expectativas antes desejadas, da reciprocidade e das obrigações sociais (Cf. Alves, 1993).

O tempo da festa, sendo uma espécie de parada cósmica, revela-se como o momento liminar em que o modo de vida e o mundo social fazem a sua passagem anual. Nessa liminaridade ritual os diferentes encontram-se, os sentimentos completam-se, os pedidos e desejos são os mesmos para quaisquer categorias sociais, daí a eleição de Nossa Senhora de Nazaré como um símbolo poderoso capaz de aglutinar diferentes interesses: todas as promessas serão pagas no dia do Círio ou nos demais da quinzena sacralizada. O Círio assinala a presença no meio do povo dessa Santa poderosa e milagrosa com a qual os devotos mantêm uma relação estreita que lhes permite atravessar esse momento extraordinário. Tratada como "rainha" da Amazônia, poderosa padroeira de todos os paraenses, realiza, no plano da representação religiosa, um poder feminino pouco correspondente no plano do mundo cotidiano. Sobre essa presença da mulher, Leach (1983, p. 129) faz referência ao Brasil no século XVIII, onde o"“culto da Virgem era excepcionalmente bem desenvolvido", como em outros casos de sociedades ditas "patriarcais" ou (como é o caso brasileiro) nas situações em que a mulher tinha pouca expressão social pública. Não é sem razão que no Brasil os grandes padroeiros são santas, Virgens Marias, cultuadas e reverenciadas, isso só para falar no catolicismo popular.

O tempo da festa realiza-se simultaneamente em espaços sacralizados. Primeiramente, no circuito que vai da Basílica de Nazaré até a Catedral de Belém. O mito de origem conta a ida da Santa da ermida até o Palácio do Governo. Hoje, a Santa, na Trasladação, sai do Colégio Gentil Bittencourt, quase ao lado da Basílica e vai para a Catedral, nas proximidades do Palácio Lauro Sodré, hoje transformado em Museu do Estado. Ao longo do trajeto, são montados pontos de parada ou de reconhecimento. A Santa é saudada com o foguetório e o baru- 
lho pertinente aos rituais públicos. No Ver-O-Peso, pelas embarcações dos pescadores e "geleiros"; na av. Castilhos França pelos estivadores e trabalhadores do porto, numa manifestação única e especial onde, inclusive, a procissão pára, dividindo assim a admiração da imensa massa de acompanhantes com uma categoria social normalmente desprovida de poder.

Aliás, o barulho do foguetório é uma característica da Festa de Nazaré, em vários momentos para anunciar, a partir da Basílica de Nazaré, o início e o fim dos festejos, ou início (seis horas) meio (doze horas) e fim (dezoito horas) de um dia na quinzena como que para anunciar à cidade que todos estão vivendo um tempo especial. No último dia da Festa - chamado o domingo da festa - no fim da noite há uma belíssima queima de fogos, como que para finalizar o período especial e já indicar um recomeço para um outro ciclo de tempo.

O arraial foi, durante muito tempo, armado no Largo de Nazaré, em frente à Basílica, mas hoje foi deslocado para uma área ao lado, onde foram instalados o parque de diversões e o conjunto de barracas com guloseimas, bebidas e outros produtos, erguendo-se na praça, o chamado, atualmente, Complexo Arquitetônico de Nazaré (CAN) com um altar e uma concha acústica. O primeiro arraial foi uma grande feira de produtos regionais, autorizado pelo Capitão-General do Rio Negro e do Grão Pará, D. Francisco de Souza Coutinho. Autorizou ele que

no dia 8 de setembro de 1793 se inaugurasse no Largo de Nazaré uma grande feira de produtos agrícolas e industriais do Estado à qual concorressem livremente os agricultores, inclusive os índios [ordenando] que em fins de agosto de cada ano deviam achar-se em Belém todas as canoas que tivessem subido ao comércio do sertão: que os diretores providenciassem de modo a ser facultado a oito ou dez indivíduos de um e outro sexo nas povoações grandes e a quatro ou seis nas povoações pequenas o embarque para a capital, a fim de virem à feira de Nazaré vender os seus produtos e os dos outros que lhes dessem incumbência de vendê-los (Viana, 1903, pp. 324-325).

Além de ser um lugar de venda, o arraial tornou-se o ponto de encontro, o lugar da festa. No arraial, durante muitos anos, funcionaram teatros que apresentavam espetáculos com artistas vindos de fora, especialmente cantores, humoristas e companhias teatrais e de teatro de revista. A permanente tentativa de manter o controle da Festa, por parte tanto das autoridades religiosas como da Diretoria da Festa, concorreu para que muitas mudanças ocorressem, sem que, na verdade, a idéia da feira, de lugar de encontro, tenha desaparecido. Nas condições atuais da cidade de Belém, complexa em seus serviços e com uma grande população, muito do que acontecia no arraial se espalhou pelo espaço urbano. Os eventos sempre são relacionados ao Círio de Nazaré e ao clima de festa então em curso: o tempo da festa chancela todas as atividades, as quais ganham um caráter especial por acontecerem exatamente durante o período. $\mathrm{O}$ espaço do arraial é demarcado simbolicamente pelos arcos de entrada e saída da Praça Justo Chermont (denominação atual do Largo de Nazaré). 
O tempo extraordinário da festa é propício à comensalidade e aos eventos que celebram o grupo familiar e comunitário. Eis porque o almoço do círio está intrinsecamente ligado à Festa do Círio e expressa em outro plano, esse tempo especial vivenciado pelos paraenses. Finda a procissão, as pessoas vão para casa para participar com familiares e amigos de um almoço especial feito, preferencialmente, de pratos regionais. O término da procissão permite aos que a acompanham um intenso momento de informalidade e relaxamento. $\mathrm{O}$ almoço reproduz a experiência vivida pelos participantes na procissão: ao reunir o grupo familiar, o indivíduo insere-se no grupo social restrito, ligado por laços formais de parentesco e amizade. No almoço, as regras de etiqueta, formais, sacralizadas, dão lugar paulatinamente às atitudes descontraídas e informais, onde há lugar, inclusive, para a jocosidade. Os laços comunitários são festejados e um sentimento de pertencimento aflora, exatamente como no contexto geral do Círio.

O código centrado na afirmação dos padrões culturais e dos laços de solidariedade entre os homens numa comunidade ideal revela-se também no tipo de alimento e na forma de prepará-lo, segundo os quais a sobreposição do cultural sobre o natural se manifesta nos ingredientes cozidos e assados a partir dos elementos naturais. $\mathrm{O}$ almoço tem como pratos principais a maniçoba e o pato no tucupi, típicos da culinária paraense. Outros pratos também são feitos e oferecidos, só que os dois primeiros exprimem mais efetivamente uma identidade revelada nas regras de comensalidade (Cf. Lévi-Strauss, 1968). O processo de transformação do cru em cozido e a mistura de diferentes cocções, traduz os códigos de uma cozinha voltada para dentro (uma endocozinha) e uma outra voltada para fora (exocozinha). A maniçoba exige um cozimento de vários dias, enquanto o pato assado, ao ser misturado ao tucupi, promove a junção de cozimentos diferentes e materiais da natureza também distintos. No almoço, o grupo mostra também a sua prodigalidade na quantidade de comida oferecida, além da hospitalidade, implícita na forma de receber, muito cara à identidade paraense.

$\mathrm{Na}$ ritualização do almoço, a dramatização estabelecida na procissão, com os atos formais de reverência e respeito e, ao mesmo tempo, de um saudável desregramento na quantidade de comida e bebida, completa no interior da casa e da família o ciclo festivo. Do ponto de vista do simbolismo culinário há uma perfeita simetria entre as transformações dadas nas técnicas de cozimento em oposição ao cru, com a predominância de regras formais e formas sociais preestabelecidas com a ausência delas. $\mathrm{O}$ triângulo, muito comum nas festas de santo, do rezar, do comer e do dançar aparece em suas variações nas diversas festas de santo, entre as quais a Festa em louvor a Nossa Senhora de Nazaré.

A linguagem dos ritos de comensalidade na Festa de Nazaré põe em relevo também um modo de dizer a respeito de valores, sistemas, representações, tal como em outros momentos da Festa. A escolha de uma certa cozinha ou formas especiais de cozimento e transformação dos alimentos em momentos rituais é diferente das escolhas e procedimentos no cotidiano. Naquela há uma marcada expressão das estruturas fundamentais de operação do mundo social. 
5 . M 5 is
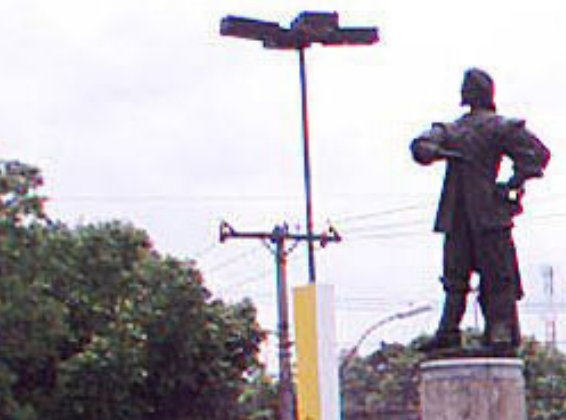

.

1

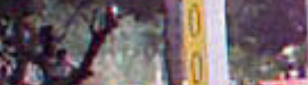

ton.

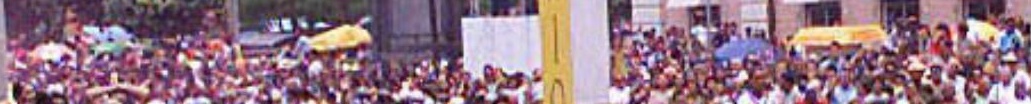

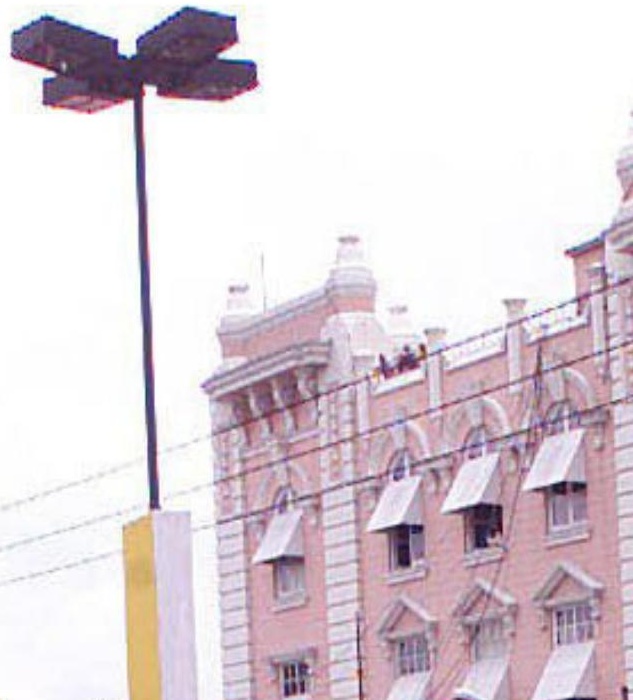

20 2.

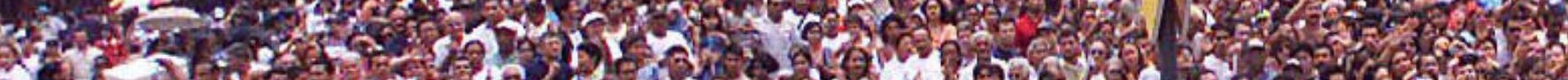

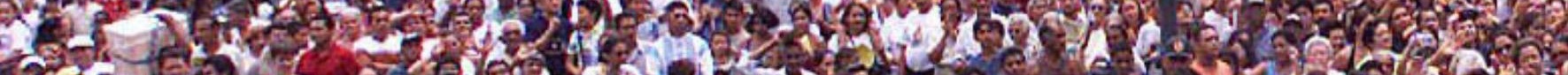
(20)

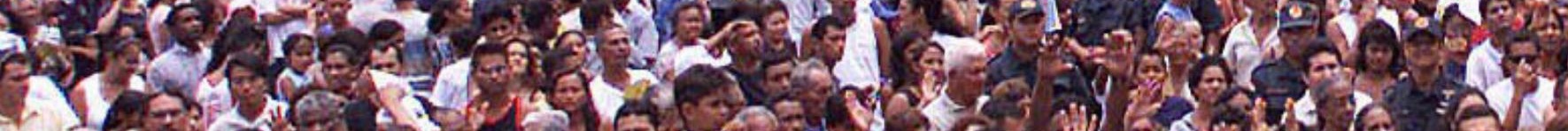

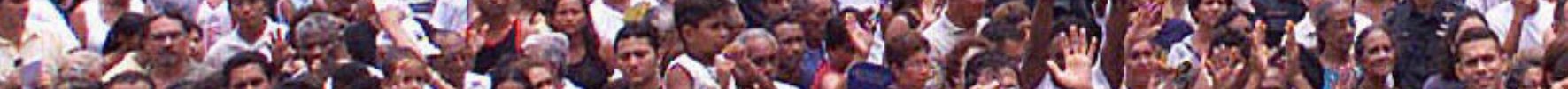
1.5.

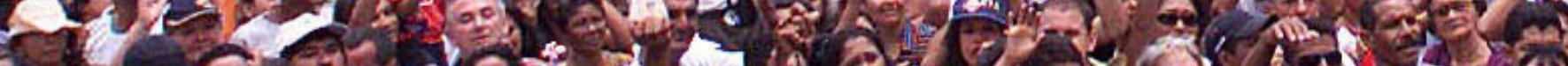

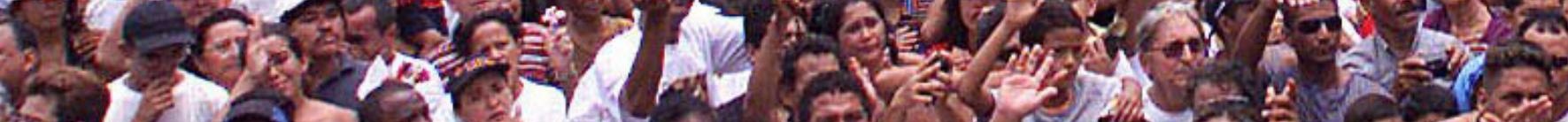

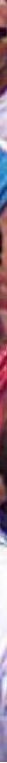


Assim é que a cozinha caracteriza-se como um outro elemento referente à identidade regional, sendo rotulada como "comida típica ou regional", que não exclui um alto grau de sofisticação. Tanto no aspecto intrínsico como no extrínsico a comida assume um duplo papel simbólico: como expressão de um código culinário voltado para o grupo familiar e como expressão de uma unidade social mais ampla, aparecendo como código $\mathrm{ideal}$, unificador, em oposição à sociedade real. Podemos observar que as relações entre o "dentro" (grupo familiar) e o "fora" (a sociedade como um todo), entre o sagrado e o profano, aparecem sob a forma tanto do código culinário como do código social.

$\mathrm{O}$ culto à Virgem e sua impressionante procissão, os festejos, o almoço, colocam em evidência - possível nos grande rituais coletivos e públicos cada um em seu momento, os atos e sentimentos que remetem a um senso de identidade, compartilhado pelos paraenses. O grande banquete simbólico é uma celebração, onde "contamos para nós mesmos" uma história que é repetida, enfatizada, ainda que, em cada uma de suas manifestações a cada ano, se identifique alguma coisa a mais ou diferente. Algumas das grandes questões do Círio (Alves, 1980) envolveram tentativas de mudanças por parte daqueles que o organizam, a Diretoria da Festa e as autoridades religiosas. Nos últimos anos, a questão da corda e da duração da procissão esteve em evidência. A corda ligada à Berlinda com a Santa e puxada pelos promesseiros tornou-se um elemento fundamental na linguagem ritual, por demarcar um espaço de extremo sacrifício e de liminaridade ritual. Em 1926, chegou a ser proibida pelo Bispo D. Irineu Jofily, tendo sido garantida, no entanto, pelo Governo do Estado (o poder civil, concorrente com o poder eclesiástico na busca de consa- 


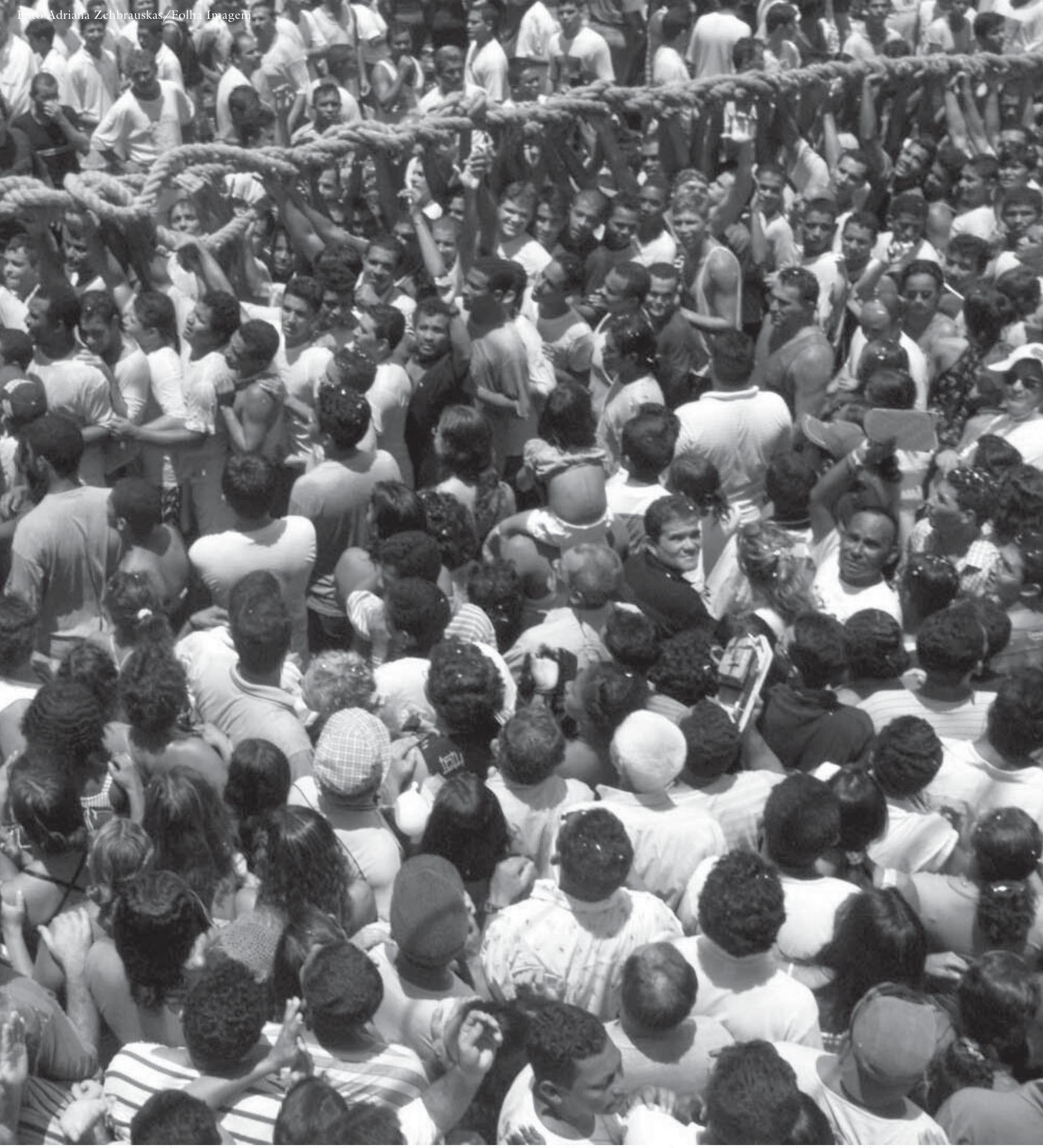

Fiéis seguram a corda durante procissão da Festa de Nossa Senhora de Nazaré, em Belém (PA).

gração derivada da realização do grande rito popular). As grandes polêmicas do Círio, na verdade, envolveram os dois aspectos de sua realização: as dimensões do sagrado e os atos profanos. Ambos são parte de uma mesma moeda cuja separação é impossível nas grandes festas religiosas. O desregramento na procissão e no arraial sempre foi objeto de intervenção do que denominamos de ideologia do controle em oposição à ideologia da communitas (Alves, 1980). De um 
lado, existe um conjunto de disposições por parte dos mandatários dos poderes concorrentes (Diretoria da Festa, autoridades eclesiàsticas, autoridades civis) e que aspiram à sacralização, que objetivam manter tanto quanto possível o controle da manifestação coletiva. De outro lado, estão as disposições coletivas no sentido da mobilização de um conjunto de símbolos que permitem, momentaneamente, aos diferentes grupos, ideais comunitários, concepções, atos e gestos informais e atitudes que não aspiram à sacralização. Tal disposição coletiva é uma espécie de resposta a uma demanda estrutural representada pela ordem e controle da festa.

A conjugação dessas diferentes disposições é que dá à Festa de Nossa Senhora de Nazaré uma dimensão peculiar, permitindo uma combinação entre opostos, um clima de conciliação no qual a padroeira é, por excelência, o símbolo aglutinador. Ao remeter as diferenças ao poder da Santa, os devotos superam as mediações que se interpõem entre o seu mundo e o do sagrado, fazendo uma conexão direta com uma intensa comunicação entre domínios e construindo os seus próprios instrumentos simbólicos de mediação (a corda, por exemplo). Naprática do ritual e na sua performance, essa conexão de domínios - do alto/ baixo, do sagrado/ profano - aparece na conjugação de categorias sociais distintas, na suspensão das barreiras sociais e na busca de uma motivação coletiva comum a todos. O povo acompanha, em sua maioria, a procissão descalço quem vai segurando a corda está sempre descalço e em completo desalinho. Pagar a promessa com extremo sacrifício significa mobilizar instrumentos que identificam diferentes grupos sociais os quais, nesse contexto, integram uma espécie de comunidade de ignais.

Quando usamos a expressão descritiva "carnaval devoto" extraída de uma passagem de um livro do escritor Dalcídio Jurandir (Belém do Grão Pará, 1960), retomada por Eidorfe Moreira (1971) dando-lhe um caráter conceitual, nosso objetivo era englobar essas duas disposições, fugindo assim à dicotomia sagradoprofano. De um lado, as ações absolutamente informais, mas que não podem chegar a uma inversão total e única (como no carnaval brasileiro) e de outro, a devoção, marcada pelo atos e comportamentos formais, com regras de acesso ao sagrado bem definidas e o respeito expresso na contrição devida à Santa.

O Círio caracteriza-se, em todo o seu trajeto, de um lado, pelas situações que expressam um profundo respeito, com os atos correpondentes, e, de outro, por uma alegria festiva demarcada pelo ritmo das músicas e das bandas que se distribuem ao longo da procissão. O drama social, no caso do Círio, é uma combinação de situações que vão do sacrifício mais doloroso de um devoto que, de joelhos ou se arrastando, paga a sua promessa, até um desregrado comportamento de quem apela para a gargalhada, a conversa amena, os votos de uma feliz festa, o estardalhaço dos jovens ou o despojamento no vestir (a camisa de um clube de futebol, por exemplo) e no andar descalço, além da expressão de uma alegre convivência com a Santa que se torna, ao descer dos altares, uma persona- 
gem familiar. Esse "carnaval devoto", com suas alegorias e sua Berlinda belamente enfeitada, é um momento de conjunção cósmica, ponto central de uma temporalidade que aponta para os sentimentos idealizados de uma sociedade que, só na aparência do contexto ritual, está em equilíbrio. Como representação dramática, esse equilíbrio é dado, de um lado pelo poder aglutinador da Santa e de outro, pela convergência das diferentes ordens de valores apontadas para um mesmo espaço e tempo, onde cada grupo e a totalidade do corpo social procuram se apropriar de um tempo e de um espaço simbólicos, o espaço sacralizado e o tempo da Festa. É assim que vemos essa magnífica Festa do Círio de Nossa Senhora de Nazaré.

\section{Referências}

ALVES, Isidoro. O carnaval devoto - um estudo sobre a festa de Nazaré, em Belém. Petrópolis, Vozes, 1980.

. Promessa é dívida - valor, tempo e intercâmbio ritual em sistemas tradicionais na Amazônia. Tese de Doutorado. Rio de Janeiro, Museu Nacional da UFRJ, 1993.

BAKHTIN, Mikhail. A cultura popular da Idade Média e no Renascimento. São Paulo, Hucitec/ Ed. da Unb, 1987.

BeLtrão, Jane F. Cólera, o flagelo da Belém do Grão Pará. Belém, Museu Emílio Goeldi/Ed. da UFPA, 2004.

DA MATTA, Roberto. Carnavais, malandros e heróis. Rio de Janeiro, Zahar, 1979. Universo do carnaval: imagens e reflexões. Rio de Janeiro, Pinakotheke, 1981.

DUBOIS, Pe. Florêncio. A devoção à Virgem de Nazaré. Belém, 1953.

GALVÃO, Eduardo. Santos e visagens: um estudo da vida religiosa de Itá, Baixo Amazonas. São Paulo, Nacional, 1955 (Coleção Brasiliana).

JURANDIR, Dalcídio. Belém do Grão Pará (Romance). São Paulo, Livraria Martins, 1960

LEACH, Edmund R. "Nascimento virgem”. Em LEACH, Edmund. São Paulo, Ática, 1983 (Coleção Grandes Cientistas Sociais, 38).

LÉVI-STRAUSS, Claude. "O triângulo culinário". EmL’arc Documentos. São Paulo, Documentos, 1968.

MAUÉS, R. Heraldo. Padres, pajés, santos e festas: catolicismo popular e controle eclesiástico. Belém, Cejup, 1995.

MOREIRA, Eidorfe. Visão geo-social do Círio. Belém, Gráfica Universitária, 1971.

SAHLINS, Marshall. Ilbas de História. Rio de Janeiro, Zahar, 1990.

VIANNA, Artur. "Festas populares do Pará". Annaes da Biblioteca e Arquivo Público do Pará, t. III. Belém, 1904. 
REsumo - Neste artigo analisa-se o Círio e a Festa de Nossa Senhora de Nazaré como um grande rito coletivo que conjuga aspectos formais e devocionais com a informalidade profana da Festa brasileira. Expressão do catolicismo popular, festividade típica do Estado do Pará, o Círio de Nazaré e os festejos que lhes são próprios englobam elementos nativos que configuram a expressão de uma identidade regional, uma temporalidade particular e uma percepção da ordem e as diferentes formas de contrastá-la.

Palavras-chave: Círio de Nazaré; festa religiosa; ritual.

Abstract - This article analyzes the Cirio [candle-lit procession] and the Feast of Our Lady of Nazaré as a great collective rite that combines formal and devotional aspects with the profane informality of a Brazilian festival. As a grass roots manifestation of Catholicism and a typical celebration of the state of Pará, the Círio of Nazaré and attending festivities embrace native elements to express a regional identity, a particular temporality, and a perception of order and differing ways to contrast it.

Key-words: Círio of Nazaré; religious feast; ritual.

Isidoro Alves é doutor em Antropologia Social e pesquisador aposentado do Ministério da Ciência e Tecnologia. @ - ialves@infolink.com.br

Recebido em 30/6/2005 e aceito em 8/7/2005. 